\title{
ばねの疲労特性に及ぼす温間ショットピーニングの効果*
}

\author{
丹下 彰**, 小山 博**, 辻 博人**

\section{Effect of Warm Shot Peening on Fatigue Strength of Spring}

\author{
Akira TANGE, Hiroshi KOYAMA and Hiroto TSUJI
}

Warm Shot Peening is well-known as the shot peening process within warm temperature range. however, the effect of warm shot peening to fatigue strength was not certain and no substantial study has been made.

The requirements of coil spring with higher fatigue strength and sag resistance have been increasing to obtain the mass saving of vehicle. While several new spring materials have been developed in recent years, the essence of those developments were to make the strength of spring higher, so-called high strengthed spring. As for high strengthened spring, the shot peening process becomes further essential to relieve the increased notch sensitivity due to higher strength, However, for the shot peening process to high strengthened spring, the shot with higher hardness is also required. This can decrease the life of both shot and shot peening equipments.

Warm shot peening under the tempering temperature may become one solution to those problems, because the hardness of spring can be temporarily reduced only during the shot peeningprocess. In this paper, the following experimental results concerned with the effect of warm shot peening, are summarized.

1) The effect of warm shot peening on fatigue life is larger for high strengthened spring. It is especially more effective when the spring hardness is over the shot hardness.

2) The appropriate temperature of warm shot peening is from 473 to $598 \mathrm{k}$.

3) The main reasons why the warm shot peening is effective to the improvement of fatigue life, are both the increase of compressive residual stress distribution and higher coverage, which can be caused by more effective deformation under warm temperature. The increase of surface hardness by warm shot peening could be an another reason for the improvement of fatigue life.

Key Words: Warm shot peening, Fatigue strength, Spring, Higher hardness.

\section{1.はじめに}

温間ピーニングは，温間温度域でショットピーニング (以下 SP) を行うことで，コットレル効果による材料強化 を期待し, 疲労強度を向上させる SP方法として, 1965 年

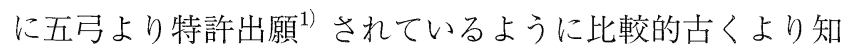
られていた技術である。しかし温間 SPは当時の追試では 顕著な効果も認められず, 著者らの知る限りその後の研究 報告もほとんどなされていない.

一方, オイルショック以来, ばねの軽量化が強く求めら れ, ばねは, より高い疲労強度と耐へたり性が求められる
ようになった。この要請に新しいばね用鋼の開発 ${ }^{22-4)}$ が盛 んとなったが，いずれもばね硬さを高くするものとなって いる.

ばね硬さを高くすることは，へたりには極めて効果的で あり，一般に疲労強度も向上するとされている。しかし， 材料の切欠き感受性が増大することから久陥の管理が厳し くなること, さらに, ばね硬さがショット硬さを上回るよ うな場合では SP加工が困難になる結果から, 疲労強度の 確保が難しくなるという重大な課題を生みだすことになる. SP加工を容易にするために，ショットを硬くするという手

\footnotetext{
原稿受付日 1998年10月14日

* ばね技術研究会1998年度春季講演会にて発表

** 日本発条(株) (NHK SPRING Co., Ltd)
} 
段があるが，硬いショットは寿命が短いという本質的な欠 点があり，経済性の面からは優れたものと思われない．

そこで，焼戻温度以下の温間での SP 加工であれば，加 工時のみ，ばねの変形抵抗を下げることが可能で，十分な $\mathrm{SP}$ 加工が達成され，かつばねの硬さを下げることもないこ とが期待される。このような背景から, 改めて温間 SPが 注目された。ここでは, (1)温間 SP 温度を一定としてばね 硬さと疲労寿命の関係, (2)ばね硬さを一定として SP 温度 と疲労寿命の関係をそれぞれ研究した。さらに，ばね鋼の 温間変形抵抗の温度依存性, 残留応力分布, カバレージお よび温間加工による材料強化の観点から疲労へおよぼす温 間 SPの効果について考察した。

\section{2. 実験条件}

\section{1ばね}

実験に用いたばね材料は，ばね鋼 JIS SUP7 相当であり， 化学組成は重量比で, C ; 0.59\%, Mn；0.85\%, Si ; 2.05\%,

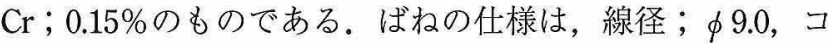
イル平均径； $\phi 84.9$, 有効巻数 ; 5.5 , ばね定数 ; $19.1 \mathrm{~N}$ /mm である. ばね硬さと疲労寿命の関係を調べる実験では, 焼入温度を $920^{\circ} \mathrm{C}$ とし, 焼戻温度を $300^{\circ} \mathrm{C}$ から $450^{\circ} \mathrm{C}$ まで 種々変えることにより，ばね硬さを HV510，550，600 およ び 650 とした。ここで，HV600 および HV650 の場合はショ ットの硬さ HV520～570を上回る硬さとなっている。また， SP 温度と疲労寿命の関係を調べる実験では, 焼戻しを温度 $350^{\circ} \mathrm{C}$, 加熱時間 60 分としてばね硬さを $\mathrm{HV} 600$ 一定とし た。

\section{2 ショットピーニング方法}

温間 $\mathrm{SP}$ 処理は，熱風循環炉を用い，ばねを $200^{\circ} \mathrm{C}$ 一 $400^{\circ} \mathrm{C}$ の雲团気中にそれぞれ 20 分放置し，ばねをほぼ雾囲 気温度まで加熱した後，直ちにSPを行うこととした。ま た，比較として，ばねを加熱せず，室温で SPを行う条件 も加えた（以下，室温 SP). SP 条件は，ショット径 $\phi 0.87$, 硬さ HV520～570 のカットワイヤ材を用い，投射速度 $66 \mathrm{~m} / \mathrm{s} ，$ アークハイト $0.42 \mathrm{mmA}$ とした。

\section{3. 実験結果と考察}

\section{1 ばね硬さと疲労寿命の関係}

室温 SP およびSP温度 $300^{\circ} \mathrm{C}$ の温間 SP したばねのそれ ぞれのばね硬さと疲労寿命の関係を Fig. 1 に示す. 室温 SP を行ったばねは，硬さの上昇に対し平均寿命は若干増加す るものの，下限寿命は変わらず，ばらつきが増し，切欠き 感受性が增大する傾向を示している。これに対し，温間 SP したばねは硬さの低い HV500 および HV550 の場合では室 温 SP したものより若干良い程度であるが，ショット硬さ を上回る HV600 と HV650 の場合では硬さの増加と共に寿 命が顕著に向上している。すなわち，温間 SP は硬いばね ほどその効果が大きいことがわかる。この結果から過去に おいて温間 SP の顕著な効果が認められなかった理由とし て，当時の実験に用いられたばねの硬さが比較的低かった

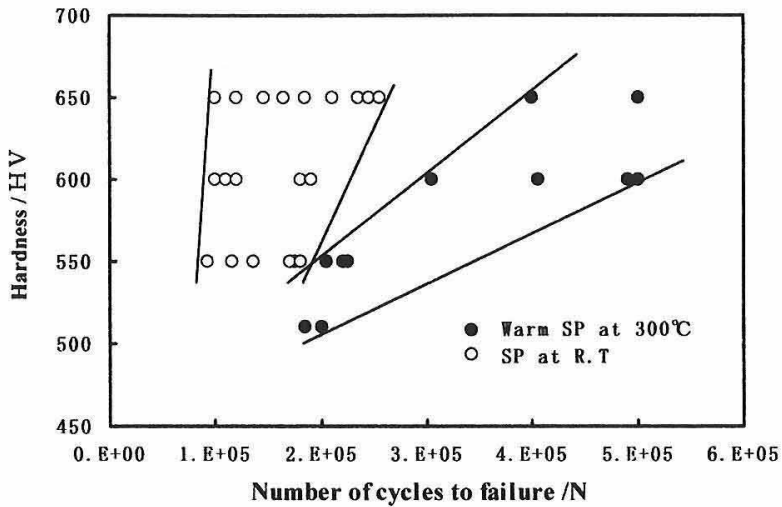

Fig. 1 Relation between spring hardness and fatigue life Stress condition ; $637 \pm 539 \mathrm{MPa}$

ためと推定される。

Fig. 2 にHV600 のばねの室温 SP したばねと温間 SP した ばねの疲労起点の近傍のそれぞれの破面とばねの表面を示 す。疲労起点はいずれも表面であるが，際だった違いは， ばね表面に残されたショットによる圧痕の大きさとカバレ ージである。室温 SP したばねは圧痕も不明瞭でカバレー ジも不充分であるのに対し，温間 SP したばねはショット の圧痕も明瞭で，カバレージも充分であることがわかる。 したがって，ばね硬さの高い場合の室温 SP したばねと温 間 SP したばねの疲労寿命の差異はショットによる加工が 前者は不充分であり，後者は充分に行われたことも大きな 理由と考えられる。この温間 SP したばねが硬いばねほど 効果が大きいことは，温間 SPが耐へたり性と疲労強度の 向上を両立させる SP 法として極めて有効な技術となり得 ることを示唆している。

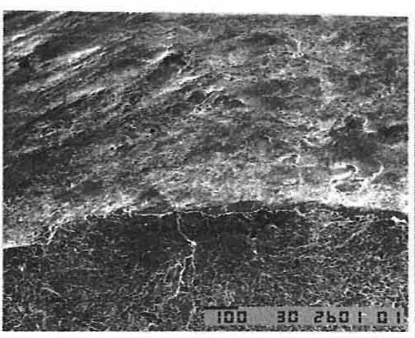

(A) SP at R.T

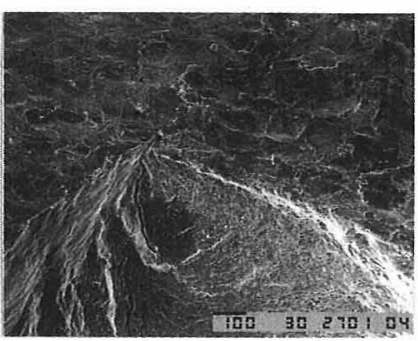

(B) Warm SP at $300^{\circ} \mathrm{C}$
Fig. 2 Comparition of fatigue fractured surface and outside surface between (A) SP at R.T and (B) Warm $\mathrm{SP}$ at $300^{\circ} \mathrm{C}$ for $\mathrm{HV} 600$

\section{2 ショットピーニング温度と疲労寿命の関係}

Fig. 3 に，硬さを HV600 としたばねの，SP 時のばねの温 度と疲労寿命の関係を示す。また同図にはSP後のばねの 最大表面粗さについても示してある。温間 SPしたばねの 平均疲労寿命は $\mathrm{SP}$ 温度 $200^{\circ} \mathrm{C}$ から $350^{\circ} \mathrm{C}$ のすべての温度範 囲で室温 SP したばねの寿命を上回っている。また，最も 疲労寿命の大きい温度範囲は $250 \sim 325^{\circ} \mathrm{C}$ にあり，それ以下 の $200^{\circ} \mathrm{C}$ 㧍よびそれ以上の $350^{\circ} \mathrm{C}$ では寿命が下がる傾向が 認められる。最大表面粗さは室温SP したばねの約 $10 \mu \mathrm{m}$ から $350^{\circ} \mathrm{C}$ の場合の $14 \mu \mathrm{m}$ まで単調に増加している。この 

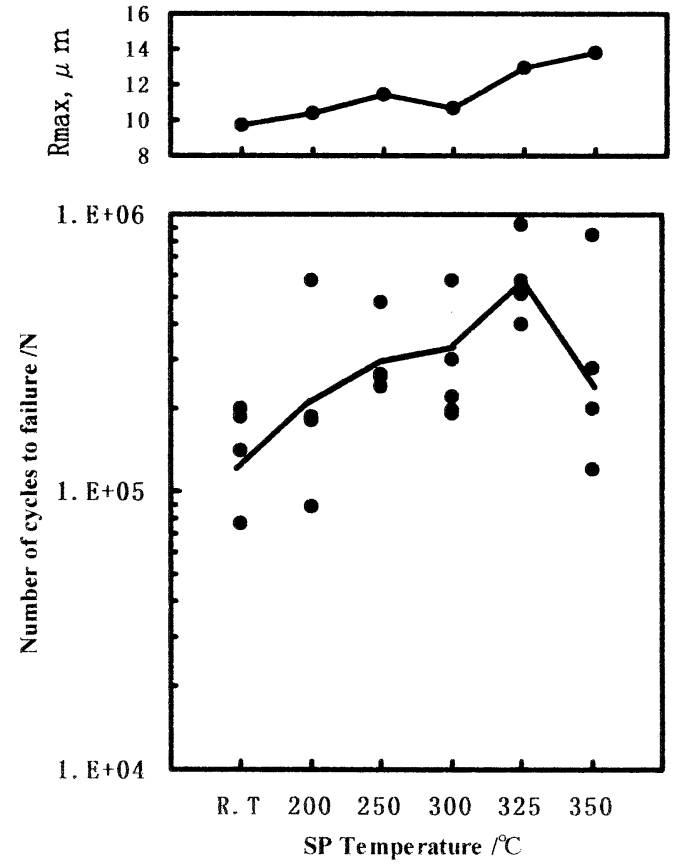

Fig. 3 Relation between SP temperature, surface roughness and fatigue life Stress condition ; 637 $\pm 539 \mathrm{MPa}$ Hardness ; HV600

表面粗さの増加は SP を受けるばねの温度が高くなるほど ばねの変形抵抗が下がるため，ばねに㧍よばすショットの 加工度が大きくなる結果と判断される。そこで SUP7を HV600 の硬さに熱処理した引張試験片（直径 $\phi 5$, 有効部 長さ50）を用いて室温から $400^{\circ} \mathrm{C}$ の温度でひずみ速度 $10 / \mathrm{min}$ と比較的早い速度で引張試験を行い，0.2\% 耐力の 温度依存性を調べた。Fig. 4 にその結果を示す。室温での $0.2 \%$ 耐力が約 $1920 \mathrm{MPa}$ であるのに対し， $200^{\circ} \mathrm{C}$ ，と $350^{\circ} \mathrm{C}$ ではそれぞれ $1650 \mathrm{MPa}$ そして $1350 \mathrm{MPa}$ と顕著に $0.2 \%$ 耐 力の低下を示していることがわかる。この結果は温間温度 域での SP加工によって，ショット硬さより硬いばねであ っても十分な SP加工を施すことが可能であることを裏付 けている.

ただし，SP加工時の加熱によってばね硬さを低下させ てはならない制約がある。したがって, 温間 SPはばねの 焼戻温度より低い温度で SPを行わなくてはならない。

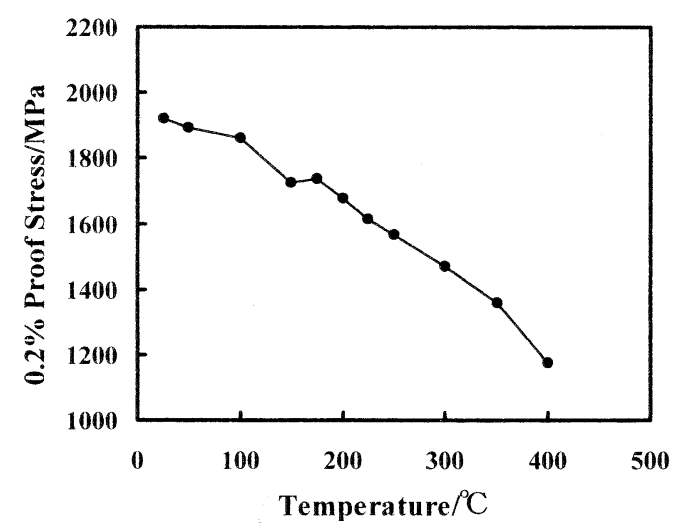

Fig. 4 Relation between temperature and $0.2 \%$ proof stress for SUP7 HV600

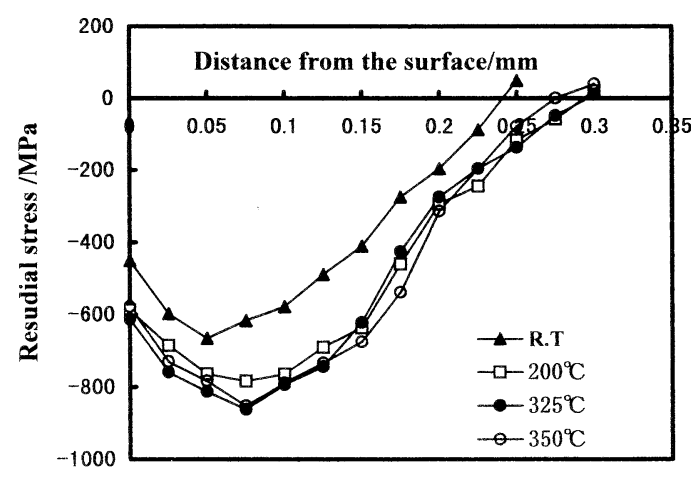

Fig. 5 Relation between SP temperature and resudial stress distribution

Fig. 5 に室温 $\mathrm{SP}$ と $200^{\circ} \mathrm{C} ， 325^{\circ} \mathrm{C}$ および $350^{\circ} \mathrm{C}$ での温間 SPで得られたばねのそれぞれの外側軸線方向の残留応力分 布を示す。室温 SP と比較し，温間でSPを行ったものは， 表面残留応力值，ピーク值のいずれも大きく，またピーク の位置抢よびクロッシングポイントも梁いことがわかる。 疲労強度に最も関係する表面からピークにかけての残留応 力分布について詳細に比較すると，その差は小さいものの $325^{\circ} \mathrm{C}$ の場合が最も大きな残留応力分布を示し, 次に $350^{\circ} \mathrm{C}$ そして $200^{\circ} \mathrm{C}$ の場合の順となっている。この表面からピー クにかけての残留応力分布が疲労き裂伝ぱ寿命に最も大き

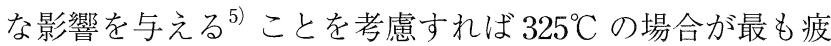
労強度が高い説明になる。また， $350^{\circ} \mathrm{C}$ の場合は表面粗さ は最も大きい。また，温間 SPでは SPによる残留応力の付 与と加熱による残留応力の開放が同時に進行しているもの と思われる。そこで, Fig. 6 に大野ら ${ }^{6)}$ の加熱による残留 応力の開放の結果を引用すると, $300^{\circ} \mathrm{C}$ までは圧縮残留応 力の低下は小さいもののそれを越えると圧縮残留応力の開 放が盛んになってくることが示されている。本実験では $325^{\circ} \mathrm{C}$ の場合が最も圧縮残留応力が大きく, 大野らの結果 と矛盾するが，SP機投入後インペラーによってばねは急冷 されるであろうことを考慮すれば， $325^{\circ} \mathrm{C}$ は $350^{\circ} \mathrm{C}$ に比べ 残留応力の開放が小さいものと推定される。この残留応力 の開放の観点からも $350^{\circ} \mathrm{C}$ 以上の加熱は疲労寿命を低下さ せるものと考えられる。

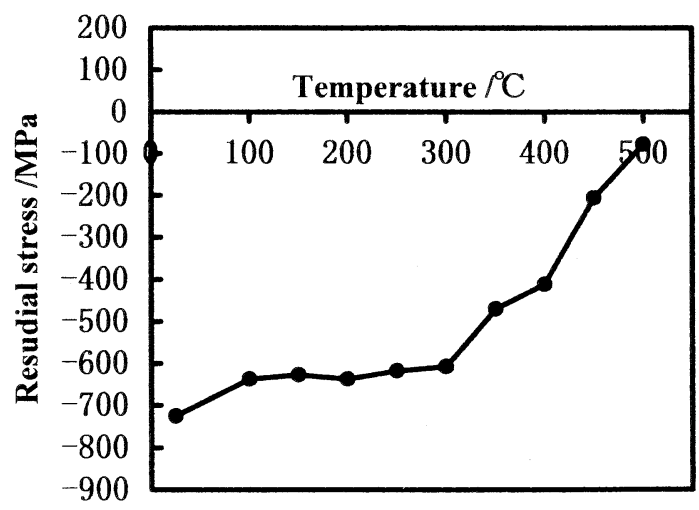

Fig. 6 Relation between temperature and relife of residual stress 


\section{3 温間加工の材料強化}

温間 SP したばねの疲労寿命の向上について, 温間加工 によるカバレージの向上と表面粗さそして残留応力分布に よって説明を行ったが，さらに温間加工が材料強度に及ほ す影響についても調査した. Fig. 7 は HV380，450，500 お よび 580 とした SUP6 の板（6t）に室温， $100^{\circ} \mathrm{C}, 200^{\circ} \mathrm{C}$, $300^{\circ} \mathrm{C}$ および $350^{\circ} \mathrm{C}$ の各温度で $\mathrm{SP}$ を行い表面近傍の硬さ分 布をコード法 ${ }^{7)} に よ り$ 詳細に調査した結果である。HV380 と HV580の分布に注目すると，室温， $100^{\circ} \mathrm{C}$ および $200^{\circ} \mathrm{C}$ の場合の硬さ分布は表面がわずかに上昇を示している程度 であるが， $300^{\circ} \mathrm{C}$ および $350^{\circ} \mathrm{C}$ の場合では $\mathrm{SP}$ 加工による加 工層深さと推定される表面から約 $0.25 \mathrm{~mm}$ にかけて硬さが 大きく増加している。その増加の程度は表面硬さで硬さの 低いHV380の場合が約 HV50であるのに対し，硬い HV580 の場合では約 HV150 と顕著な増加を示している．中間の硬 さの HV450 および HV500もこの傾向と同様で，かつ硬さ の増加も中間である。この硬さの増加は五弓の主張するコ ットレル効果，すなわち温間 SP 中に導入された転位への フリーC， $\mathrm{N}$ の固着による動的ひずみ時効の効果と考えら

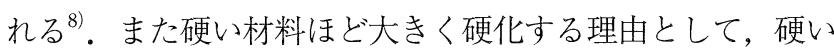
材料ほど焼戻温度が低いためフェライト中に過飽和に固溶 していたCおよび $\mathrm{N} の$ 量が多いため柔らかい材料よりひず み時効が盛んになったと推定される。

温間 SP したばねの疲労寿命が向上する理由としてこの 温間加工による硬さの増加も大きく寄与しているものと思 われる。この寄与は実験結果から，より高温側の温間 SP, すなわち $300^{\circ} \mathrm{C}$ 以上で大きい.
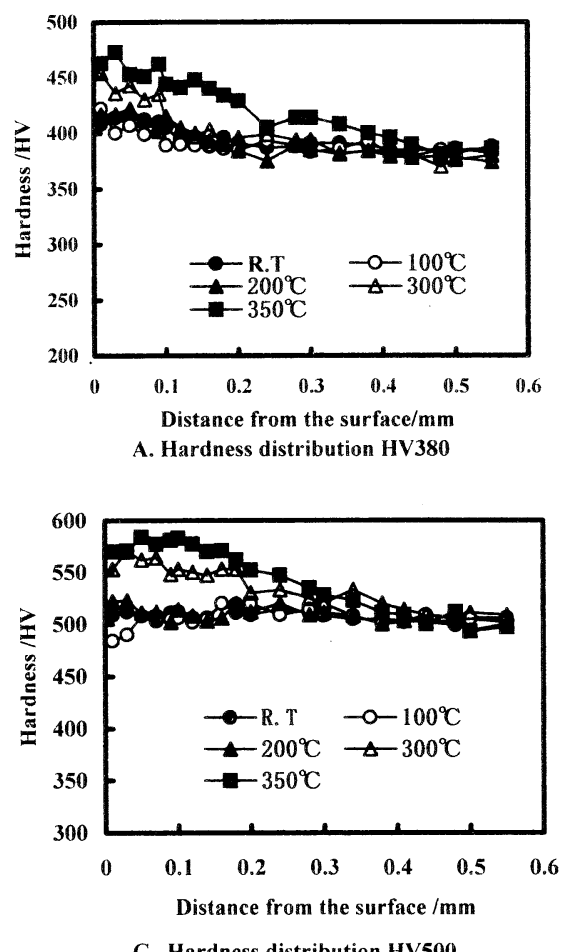

C. Hardness distribution HV500

\section{4. まとめ}

（1）温間 SP の疲労強度向上の効果は硬いばねほど大きい. 特に,ばね硬さがショット硬さを上回る場合に有効で ある。

(2) 温間 SP 加工の温度は $250 \sim 325^{\circ} \mathrm{C}$ でその効果は大きい.

（3）温間 SPは耐へたり性と疲労強度の向上を両立させる $\mathrm{SP}$ 技術となりうる。

(4) 温間 SP の疲労強度向上の理由は, 温間加工により SP の加工が容易になりばね表面に大きく深い残留応力場 が形成されることと, カバレージの向上，さらに温間 加工による表面層の強度上昇であることがわかった。

\section{参考文献}

1）五弓 勇雄，特許 第 725630 号 1974 年

2）阿久津忠良，丹下 彰，佐藤保夫，新井康夫，飯 久保知人，伊藤幸夫，ばね技術研究会 昭和 62 年 度 春季講演会前刷集，1-4.

3) Abe, M., Taniguchi, T., Kuriki, T., Saitoh, K. and Takamura, N., SAE Technical Paper Series 890220.

4) 中野 修, 安田 茂, 水野邦明, 自動車技術会論 文集, Vol. 24, No. 3, July（1993）,61.

5）丹下 彰，阿久津忠良，高村典利，ばね論文集， 36号 (1991)，47.

6）大野 明，材料試験 5,35 (1956)，476.

7) Gassner, R. H., METAL PROGRESS, March (1978), 59.

8）田村今男，“鉄鋼材料強度学”，(1969）, p. 271，日 刊工業新聞社.
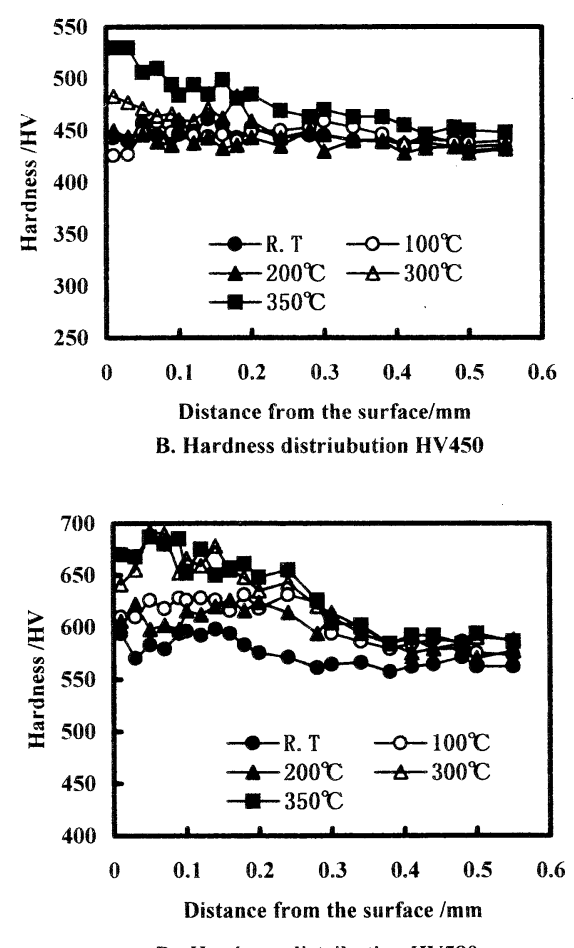

D. Hardness distribution HV580

Fig. 7 Hardness distributions around the surface, for SUP6 plates with the hardness of HV380, HV450, HV500 and HV580, shot peened at R. T, $100^{\circ} \mathrm{C}, 200^{\circ} \mathrm{C}, 300^{\circ} \mathrm{C}$ and $350^{\circ} \mathrm{C}$ 